\title{
Transparent Conducting ZnO Thin Films Prepared at Room Temperature by PLD Method
}

\author{
Hideaki Agura Student Member, Yasunori Takase Student Member, Kenji Uehara Student Member, \\ Atsuhiro Nakamura Student Member, Yoshinori Higashimura Student Member, \\ Takanori Aoki Member, Akio Suzuki Member, Tatsuhiko Matsushita Member (Department of \\ Electronics, Information and Communication Engineering, Osaka Sangyo University) \\ Masahiro Okuda Member (Okuda Technical Office) \\ Hirokazu Okinaka Non-member (Hitachi High-Technologies Corporation)
}

Keywords : Pulsed Laser Deposition Method, Transparent Conducting Oxide Films, Zinc Oxide, Crystal structure

Today, transparent conducting oxide (TCO) films have become indispensable to electrodes in optoelectronic devices such as liquid crystal displays, plasma displays and organic electroluminescent display panels. Though almost all TCO films now being put to practical use are made of indium tin oxide (ITO), a compound is likely to become unavailable due to the growing depletion of its component metal indium, one of the rare metal elements, produced as by-products of zinc. Therefore, a great deal of interest has turned to TCO films based on a zinc oxide system because of its advantage such as non-toxicity and cheapness derived from being of abundance. Lately, a pulsed laser deposition (PLD) method has been widely adopted as a means of preparing high-quality thin film devices including TCO films. It is expected that one will obtain transparent conducting $\mathrm{ZnO}$ thin films with good crystallinity. So, we tried to fabricate $\mathrm{Al}_{2} \mathrm{O}_{3}$-doped $\mathrm{ZnO}$ (AZO) and $\mathrm{Ga}_{2} \mathrm{O}_{3}$-doped $\mathrm{ZnO}$ (GZO) films at room temperature on the glass substrate using the SHG $(\lambda=532 \mathrm{~nm})$, THG $(\lambda=$ $355 \mathrm{~nm})$ and FHG $(\lambda=266 \mathrm{~nm})$ of Nd:YAG laser. As a results, it was found that with more shorter wavelength, more excellent films were obtained, including good electrical properties and crystallinity.

Figure 1 shows film thickness dependence of electrical properties for GZO films deposited using ArF excimer laser (resistivity $\rho$, carrier concentration $n$ and mobility $\mu$ ): we succeeded to fabricate the $416 \mathrm{~nm}$-thick GZO film with the lowest resistivity of $2.89 \times 10^{-4} \Omega \cdot \mathrm{cm}$. Moreover, we studied whether the film properties were subject to influences of the position of the plume (in the central axis or at the periphery) generated between the substrate and the target.

Figure 2 shows high-resolution FE-TEM images of AZO films fabricated with ArF excimer laser: (a) crystal-lattice image of the center of the AZO films, grown in the periphery of the plume, (b)

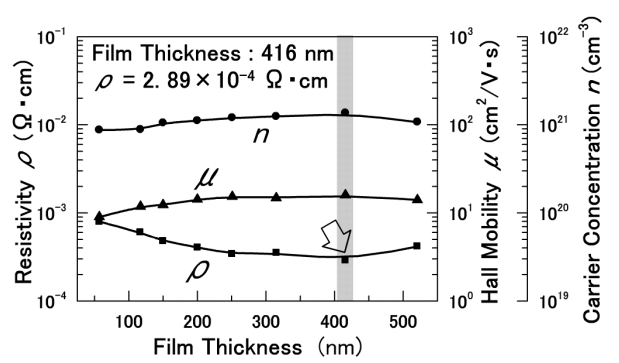

Fig. 1. Film thickness dependence of electrical properties for GZO films deposited using ArF excimer laser crystal-lattice image of the center of the AZO films, grown in the center of the plume, (c) crystal-lattice image at the interface between the substrate and the AZO films, grown in the periphery of the plume, (d) crystal-lattice image at the interface between the substrate and the AZO films, grown in the center of the plume, (e) electron diffraction pattern of the case (c), and (f) electron diffraction pattern of the case (d), and (g) illustration of the position of (a) $\sim(f)$. It was recognized that from the result of the case (c), disagreement of the alignment of lattice slightly appeared for the interface between the substrate and the AZO films, grown in the periphery of the plume, and that from the result of the case (d), the crystal-lattice was regularly aligned in the AZO films, grown in the center of the plume, respectively. It was considered that the difference seen in the case (c) and (d) was caused by the difference of magnitude of the plasma density generated in the plume.
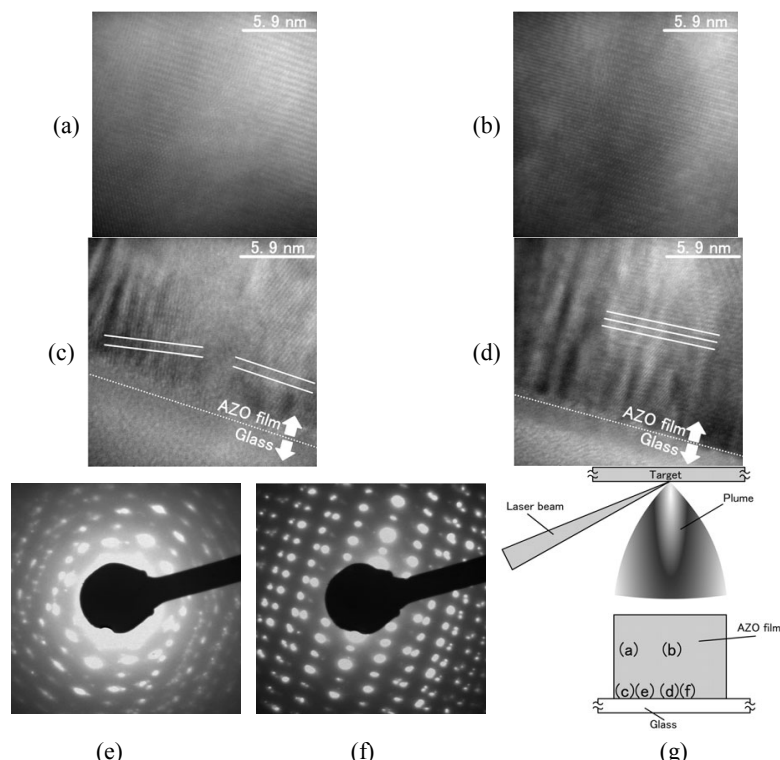

(g)

Fig. 2. High-resolution FE-TEM images of the AZO films fabricated with ArF excimer laser : (a)(b)crystal-lattice image in the center of the AZO films, (c)crystal-lattice image at the interface between the substrate and the AZO films, grown in the periphery of the plume, (d)crystal-lattice image at the interface between the substrate and the AZO films, grown in the center of the plume, (e)(f)electron diffraction pattern and (g) illustration of the position of (a) (f) 


\section{パルスレーザ堆積法により低温基板に作製した 酸化亜鉛系透明導電膜}

$\begin{array}{llllll}\text { 学生員 安倉 秀明* } & \text { 学生員 高瀬 康則* } & \text { 学生員 上原 賢二* } \\ \text { 学生員 中村 篤宏* } & \text { 学生員 東村 佳則* } & \text { 正 員 青木 孝憲* } \\ \text { 正 員 鈴木 晶雄* } & \text { 正 員 松下 辰彦* } & \text { 正 員 奥田 昌宏** } \\ \text { 非会員 沖中 広和*** } & & & & & \end{array}$

\section{Transparent Conducting ZnO Thin Films Prepared at Room Temperature by PLD Method}

Hideaki Agura*, Student Member, Yasunori Takase*, Student Member, Kenji Uehara*, Student Member,

Atsuhiro Nakamura*, Student Member, Yoshinori Higashimura*, Student Member, Takanori Aoki*, Member,

Akio Suzuki*, Member, Tatsuhiko Matsushita*, Member, Masahiro Okuda**, Member, Hirokazu Okinaka***, Non-member

Al-doped zinc oxide (AZO) or Ga-doped zinc oxide (GZO) films with c-axis orientation have been deposited on glass substrates by pulsed laser deposition (PLD) using an $\operatorname{ArF}$ excimer laser $(\lambda=193 \mathrm{~nm})$ or Nd:YAG laser $(\lambda=532,355,266 \mathrm{~nm})$. The film deposition took place at substrate temperatures of room temperature $\left(25{ }^{\circ} \mathrm{C}\right) \sim 200{ }^{\circ} \mathrm{C}$. For the GZO film deposited by irradiating a pulsed laser beam of energy density of $1 \mathrm{~J} / \mathrm{cm}^{2}$ at repetition frequency of $10 \mathrm{~Hz}$, we obtained the $416 \mathrm{~nm}$-thick GZO film with the lowest resistivity of $2.89 \times 10^{-4} \Omega \cdot \mathrm{cm}$ for the case at a substrate temperature of room temperature. An average transmittance of more than $80 \%$ in the visible region was obtained for the GZO films fabricated, providing useful functionality as TCO films in the visible region. Moreover, we studied whether the film properties were subject to influences of the position of the plume (in the central axis or at the periphery) generated between the substrate and the target.

キーワード : PLD 法, 透明導電膜, 酸化亜鈆, 結晶構造

Keywords : Pulsed Laser Deposition Method, Transparent Conducting Oxide Films, Zinc Oxide, Crystal structure

\section{1. まえがき}

近年，ディスプレイデバイスの分野では，液晶ディスプ レイ(LCD)及びプラズマディスプレイ(PDP), 最近, 特に研 究が盛んに行われている有機 EL ディスプレイなどフラッ トタイプのディスプレイがブラウン管に替わるディスプレ イとして急速に普及し始めている。これらフラットタイプ のディスプレイには共通して酸化物透明導電膜(TCO： Transparent Conducting Oxide)が透明電極として用いられて

* 大阪産業大学 工学部 電子情報通信工学科

厂574-8530 大阪府大東市中垣内 3-1-1

Department of Electronics, Information and Communication

Engineering, Osaka Sangyo University

3-1-1 Nakagaito, Daito, Osaka, 574-8530

** 奥田技術事務所

厂591-8032 大阪府堺市百舌鳥梅町 1-2-27

Okuda Technical Office

1-2-27 Mozu-Umemachi, Sakai, Osaka 591-8032

*** 株式会社 日立ハイテクノロジーズ

T105-8717 東京都港区西新橋 1 丁目 24 番 14 号

Hitachi High-Technologies Corporation

1-24-14 Nishi Shimbashi, Minato-ku, Tokyo 105-8717

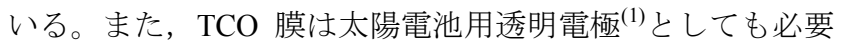
不可欠な存在である。現在, 広く用いられている透明導電 膜のほとんどはインジウム・スズ酸化物（ITO : Indium Tin Oxide）系透明導電膜 ${ }^{(2)}(5)$ であるが，インジウムが希少金属 であることから安定供給に懸念がある。そこで最近, 資源 が豊富で人体にも無害な酸化亜鉛 $(\mathrm{ZnO})^{(6) \sim(17)}$ を用いた透明 導電膜 ${ }^{(14) \sim(21)}$ が注目されている。近年, 高品質な薄膜デバイ スを作製する手法としてパルスレーザ堆積（PLD： Pulsed Laser Deposition）法(22) (34)が注目され, 高温超伝導体の作製 や透明酸化物半導体デバイス(TOS：Transparent Oxide Semiconductor)の作製に関する研究も多く報告されている (7)(8)(10),(13)。しかしながら, PLD 法により透明導電膜を実用 化する際, 成膜レートが低く, 大面積化が困難であるとい う問題点を抱えており, 種々の解決方法が模索されている (4)。今回, 著者らはレーザ光源に $\mathrm{ArF}$ エキシマレーザおよび $\mathrm{Nd}$ :YAG レーザを用いた PLD 法で, $\mathrm{ZnO}$ 系透明導電膜とし て高品質な薄膜が得られる $\mathrm{AZO}\left(\mathrm{Al}_{2} \mathrm{O}_{3}\right.$ を添加した $\left.\underline{\mathrm{ZnO}}\right)$ お 
よび GZO（ $\underline{G a}_{2} \mathrm{O}_{3}$ を添加した $\underline{\mathrm{Z}} \underline{\mathrm{O}} ）$ 透明導電膜を作製した。 通常, 透明導電膜を成膜する際には $200{ }^{\circ} \mathrm{C}$ 以上の高温にて 熱処理を施さなければならないため, 耐熱性に優れたガラ スを用いることで高品質な薄膜を作製しているが(17) (21), 今 回の実験では基板温度 $200{ }^{\circ} \mathrm{C}$ 以下の低温成膜にて成膜時間 の短縮化，有機基板を用いることによる軽量化を目指す心゙ く ${ }^{(34)}$, 主として基板温度を室温として成膜を行った。基板 温度を室温とすることで, 従来の成膜にかかる昇温・降温 のプロセスが省けることから約半分の成膜時間とすること ができる。また, 過去に Nd:YAG レーザの第 2 高調波 $(\lambda=$ $532 \mathrm{~nm}$ ) を用い，テクスチャ構造を有する $\mathrm{GZO}$ 透明導電膜

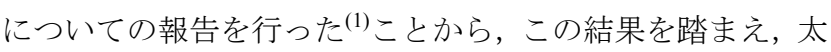
陽電池用の透明電極としての利用を目指寸べくレーザ光源 波長依存性について分析を行った。さらにレーザを照射し た際に発生するプラズマプルームの挙動を調べるため場所 依存性について分析を行った。これらの分析には高分解能 FE-TEM を用い結晶構造の分析を詳細に行った。

\section{2. 実験装置および方法}

成膜は表 1 の条件で行った。酸化亜鉛系透明導電膜はコ ーニング\#7059 ガラス基板 $(26 \mathrm{~mm} \times 38 \mathrm{~mm} \times 1.1 \mathrm{~mm}$ 厚 $)$ 上 に $1 \mathrm{~cm}^{2}$ 四方の大きさとなるように成膜し, 基板温度は室温 $\left(25{ }^{\circ} \mathrm{C}\right) \sim 200{ }^{\circ} \mathrm{C}$, 成膜レートは約 $5 \mathrm{~nm} / \mathrm{min}$. とした。酸 化亜鉛系材料は PLD 法で基板温度を室温にて成膜を行うと $\mathrm{Zn}$ リッチな膜となり, 透過率が減少することから室温成膜 の実験ではチャンバー内の酸素䨌囲気圧をマス・フロー・ コントトーラを用いて酸素を導入しない真空排気状態 $\left(10^{-4}\right.$ $\mathrm{Pa}$ 台）から $1.6 \mathrm{~Pa}$ まで成膜条件を変化させ，最も低い抵抗 率の膜が得られた 0. $5 \mathrm{~Pa}$ の場合を最適条件とした。基板温 度の違いにより, 酸素䨌囲気圧の最適值も異なることから これらの実験の際にも同様に酸素雰囲気圧を変化させて最 適条件を求めたのち, 実験を行った。

実験に用いたレーザは波長 $193 \mathrm{~nm}$ の $\mathrm{ArF}$ エキシマレーザ および波長 532， 355， $266 \mathrm{~nm}$ の Nd:YAG レーザである。 ターゲットには $\mathrm{AZO}\left(\mathrm{Al}_{2} \mathrm{O}_{3}: 1.5\right.$ wt. \%)または $\mathrm{GZO}\left(\mathrm{Ga}_{2} \mathrm{O}_{3}: 3\right.$ wt. \%)の純度 $99.99 \%$, $50 \mathrm{~mm} \phi \times 5 \mathrm{~mm}$ 厚の焼結体を用い た。また，レーザビームが 1 点に集中してターゲットが損 傷しないようにパソコンとパルスモータでプログラマブル 制御し, 往復回転運動させて成膜した。その他の成膜条件 は表 1 に示す通りである。

図 1 に成膜に用いたチャンバーの概略図を示す。成膜され た透明導電膜は以下の装置を用いて評価を行った。電気的 特性は van der Pauw の 4 探針法によるホール効果測定 (BIO-RAD, HL5500PC), 光学的特性は分光光度計 (Hitachi, U-3500), 表面・断面観察は高分解能電界放出型走查電子顕 微鏡 (Hitachi, S-4700, 以下 FE-SEM), および原子間力顕 微鏡 (Topometrix, TMX-2000, 以下 AFM), 結晶構造解析 は $\theta-2 \theta$ スキャン法による X 線回折装置（Shimadzu， XRD-6100, 以下 XRD) およびマイクロサンプリングユニッ 卜付集束イオンビーム加工観察装置（Hitachi， FB-2000A）
Table 1. Preparation Conditions

\begin{tabular}{|c|c|}
\hline Laser & $\begin{array}{l}\text { ArF Excimer Laser } \\
(\lambda=193 \mathrm{~nm}) \\
\text { Nd:YAG Laser } \\
(\lambda=532,355,266 \mathrm{~nm})\end{array}$ \\
\hline Laser Energy & $50 \sim 100 \mathrm{~mJ}$ \\
\hline Laser Energy Density & $1 \sim 2 \mathrm{~J} / \mathrm{cm}^{2}$ \\
\hline Repetition Frequency & $10 \mathrm{~Hz}$ \\
\hline Target to Substrate Distance & $40 \mathrm{~mm}$ \\
\hline Target & $\begin{array}{l}\text { AZO }\left(\mathrm{Al}_{2} \mathrm{O}_{3}: 1.5 \text { wt. \%) or }\right. \\
\text { GZO }\left(\mathrm{Ga}_{2} \mathrm{O}_{3}: 3 \text { wt. \%) }\right.\end{array}$ \\
\hline Substrate & Corning \#7059 \\
\hline Substrate Temperature & Room Temperature $\left(25^{\circ} \mathrm{C}\right) \sim 200{ }^{\circ} \mathrm{C}$ \\
\hline Base Pressure & $\sim 10^{-4} \mathrm{~Pa}$ \\
\hline Gas Pressure & $0 \sim 1.6 \mathrm{~Pa}\left(\right.$ in $\left.\mathrm{O}_{2}\right)$ \\
\hline
\end{tabular}

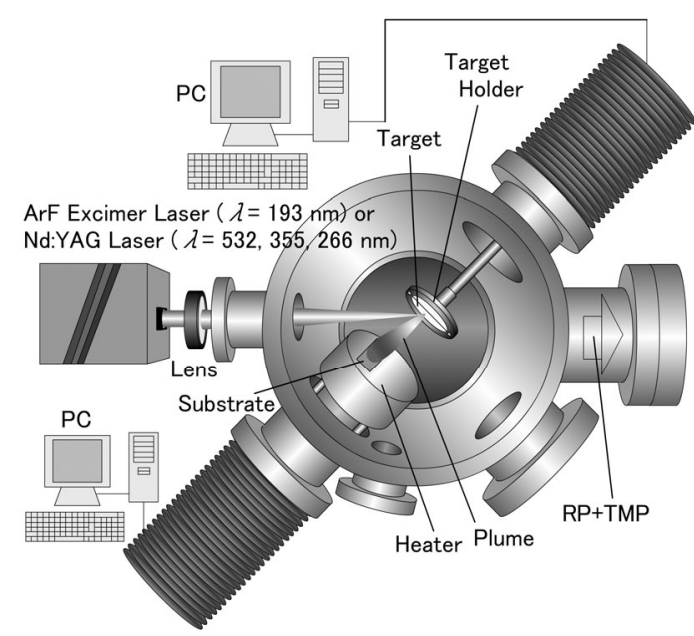

Fig. 1. Illustration of pulsed laser deposition system for AZO films using ArF excimer laser or Nd:YAG laser

を用いて加工の後, 高分解能電界放出型透過電子顕微鏡 （Hitachi，HF-2000, 以下 FE-TEM）を用いてそれぞれ評価を 行った。

\section{3. 実験結果及び考察}

〈3・1〉 AZO 透明導電膜のレーザ光源波長依存性 本 実験では, ArF エキシマレーザで不可欠の面倒なガス交換作 業が不要でメンテナンス性およびランニングコストに優れ た Nd:YAG レーザを用い, 第 $2 \cdot 3 \cdot 4$ 高調波 $(\lambda=532,355$, $266 \mathrm{~nm}$, 以下 $\mathrm{SHG}, \mathrm{THG}, \mathrm{FHG})$ にて基板温度を $200{ }^{\circ} \mathrm{C}$ と して AZO 透明導電膜を作製した。図 2 にこれらを用いて作 製した薄膜を FE-SEM にて膜表面・断面を観察した結果を 示す。同図(a)の SHG および(b)の THG で成膜を行った場合, 膜表面にはドロップレットの痕跡が確認できた。(c)の FHG で成膜を行った場合はドロップレットの痕跡は確認されな かった。また, 波長が短くなるにつれて膜が密に詰まった 構造となっていることがわかった。以上の結果より, 波長 を変化させて成膜を行うことでアブレーション過程が異な り膜構造が大きく異なった AZO 透明導電膜が成膜されるこ とがわかった。

次に, AZO 透明導電膜を作製する際のレーザ光源波長の 違いによる特性変化の要因を FE-TEM にて分析を行った。 


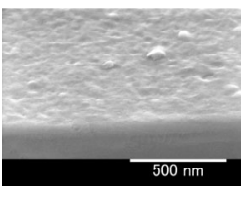

(a)

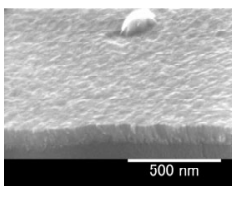

(b)

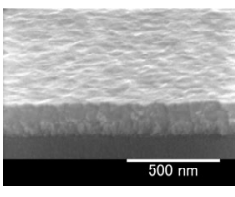

(c)

Fig. 2. FE-SEM images for the surface of AZO films deposited with Nd:YAG laser : (a)SHG, (b)THG and (c)FHG

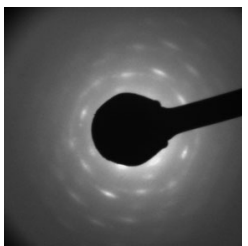

(a)

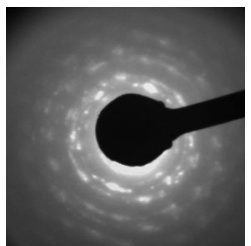

(b)

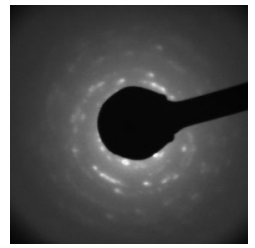

(c)

Fig. 3. Electron diffraction pattern of the AZO films deposited with Nd:YAG laser : (a)SHG, (b)THG and (c)FHG

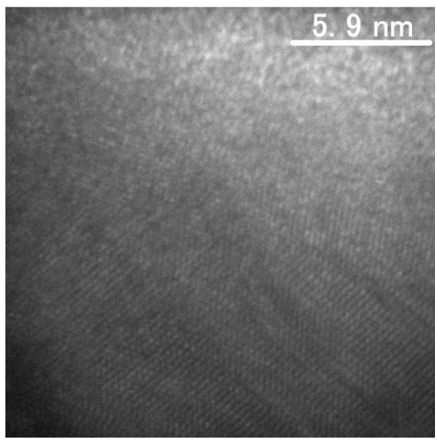

(a)

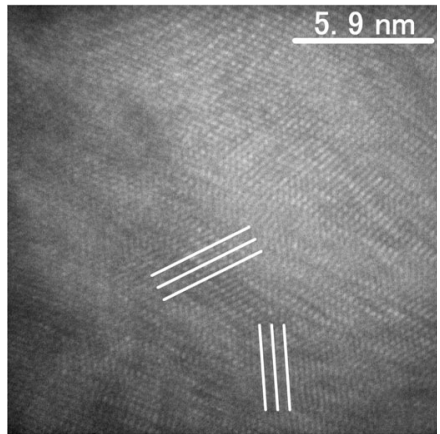

(d)

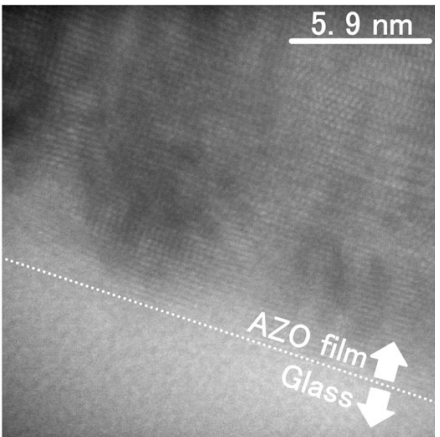

(g)

SHG

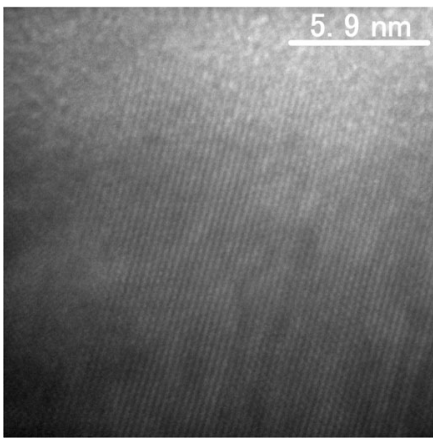

(b)

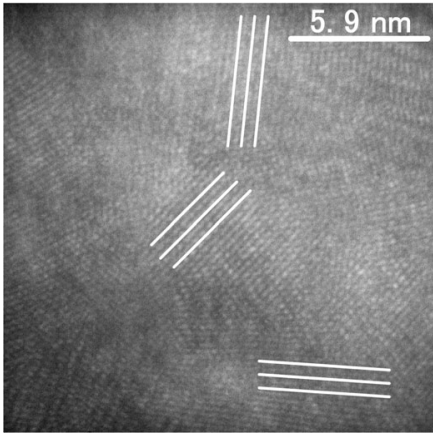

(e)

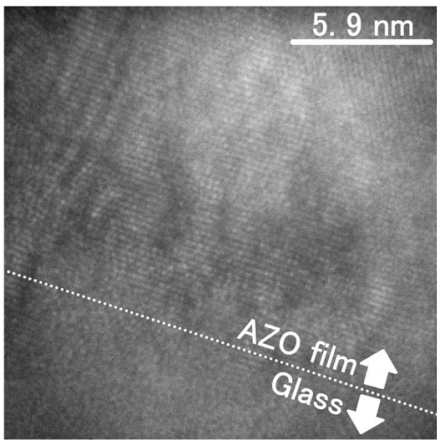

(h)

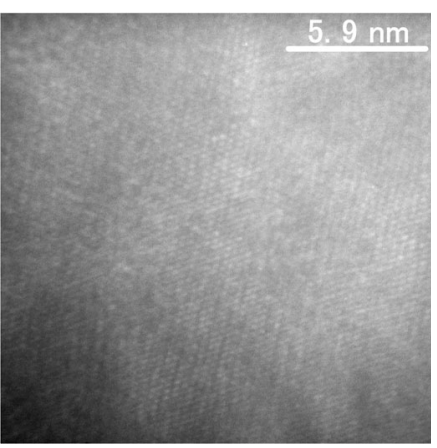

(c)

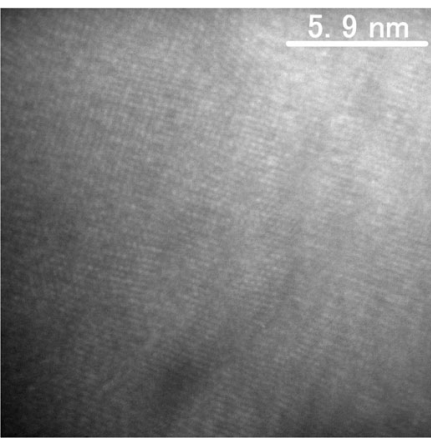

(f)

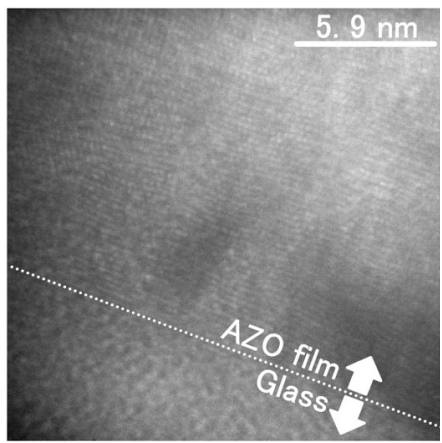

(i)

Fig. 4. High-resolution FE-TEM images of the AZO films fabricated with Nd:YAG laser : (a)(b)(c)crystal-lattice image in the surface of the AZO films, (d)(e)(f)crystal-lattice image in the center of the AZO films and (g)(h)(i) crystal-lattice image at the interface between the substrate and the AZO films

図 3 に Nd:YAG レーザの SHG, THG, FHG で成膜を行った場 合の電子線回折パターンを示す。いずれの膜も明瞭な回折 点は観測されず，結晶性が良くない膜構造となっているこ とがわかった。

次に図 4 に Nd:YAG レーザで成膜を行った場合の結晶格 子像を示す。図(g)(h)(i)より, いずれの波長で成膜を行った
場合もガラス基板と AZO 透明導電膜の界面部分では格子の 大きな乱れは確認できなかったが, 図(d)(e)の SHG, THG で 成膜を行った場合は膜中央層付近で格子欠陥が多数存在し た。これは, 波長が短い紫外光の場合は分子の化学結合を 切断するための十分なエネルギーを有し(35), エピタキシャ ル成長のような密に詰まった膜構造を形成するのに対し, 
波長が長い場合はこれらのエネルギーに達しないため，溶 融現象が支配的なアブレーション状態となったため成長す るにつれて格子の歪みが増大したためではないかと考えら れる。また, FHG で成膜した場合は膜中央層付近(f)で格子 欠陥が少なく, 結晶性の良い膜となっていることが確認で きた。

〈3.2〉 FHG で作製した $A Z O$ 透明導電膜の基板温度依 存性 $\quad 3.1$ の実験にて, FHG で成膜を行うことで良好な透 明導電膜を作製可能であることがわかったため，次に基板 温度の依存性について調べた。同時に, チャンバー内の酸 素雾囲気圧を $0.5 \sim 1.6 \mathrm{~Pa}$ と変化させ, $1.5 \mathrm{~Pa}$ の時に最も 抵抗率が減少したことから, 最適值を $1.5 \mathrm{~Pa}$ とした。

図 5 にこれらの膜をXRD により分析した結果を示す。こ の結果より, 基板温度を下げるにつれて $\mathrm{ZnO}(0002)$ 面の回折 ピークは小さくなっているが，基板温度が室温の場合でも 僅かではあるが膜が結晶化していることが確認できた。

次に図 6 に FHG にて基板温度を変化させて成膜した膜の 表面・断面像を FE-SEM およびAFMにより観察した結果を 示す。同図(a)の基板温度を $200{ }^{\circ} \mathrm{C}$ とて成膜を行った場合 は膜表面が密に詰まった構造となっていることが FE-SEM 像および AFM 像から確認できる。これは，基板温度を下げ るにつれて粒子一つ一つの粒径が大きくなったため（AFM により測定した表面平均粗さ $R a$ の值が大きいことより判 断）と考えられる。また, 表面平均粗さ $R a$ の值も基板温度 を下げることにより大きくなることがわかった。

\section{$\langle 3 \cdot 3\rangle \quad \mathrm{AZO} \cdot \mathrm{GZO}$ 透明導電膜の室温成膜 3.1 およ} び 3.2 の実験にて, レーザ光源の波長が短波長になるにつれ て結晶構造が顕著に改善されることがわかったため, Nd:YAG レーザよりもさらに短波長の光を発振できる波長 $193 \mathrm{~nm}$ の $\mathrm{ArF}$ エキシマレーザを用い，膜厚を変化させて室 温成膜したときの透明導電膜の電気的特性（抵抗率 $\rho$, 木

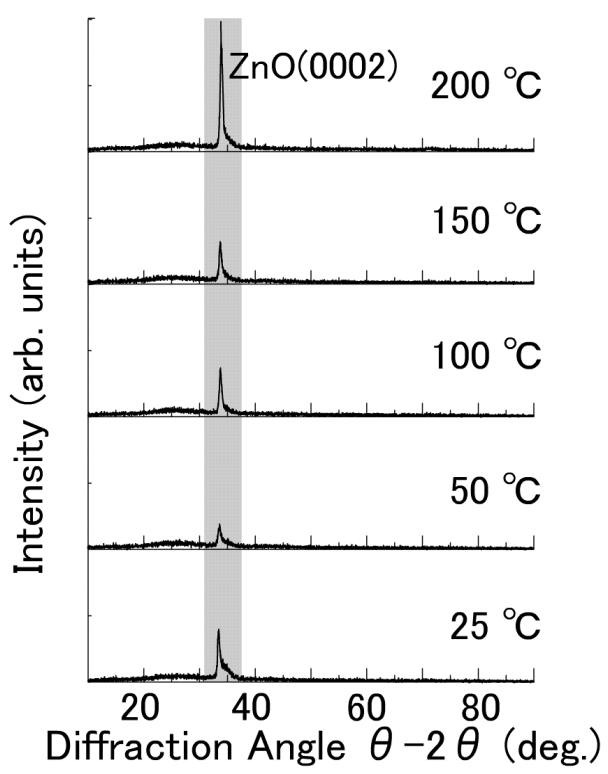

Fig. 5. Substrate temperature dependence of XRD spectra for AZO films fabricated using FHG of Nd:YAG laser
一ル移動度 $\mu$, キャリア密度 $n$ ) を図 7 に示す。同図(a)のタ ーゲットに AZO を用いて成膜を行った場合, 膜厚が $407 \mathrm{~nm}$ の時, 最小抵抗率 $\rho=3.16 \times 10-4 \Omega \cdot \mathrm{cm}$ (ホール移動度 $\mu$ $=19.9 \mathrm{~cm} 2 / \mathrm{V} \cdot \mathrm{s}$, キャリア密度 $\left.n=9.95 \times 10^{20} \mathrm{~cm}^{-3}\right)$ を得た。 また, 同図(b)のターゲットに GZO を用いて成膜を行った場 合, 膜厚が $416 \mathrm{~nm}$ の時, 最小抵抗率 $\rho=2.89 \times 10^{-4} \Omega \cdot \mathrm{cm}$ (ホール移動度 $\mu=15.9 \mathrm{~cm}^{2} / \mathrm{V} \cdot \mathrm{s}$, キャリア密度 $n=1.36$ $\left.\times 10^{21} \mathrm{~cm}^{-3}\right)$ を得た。通常, 透明導電膜は熱処理を施すこと

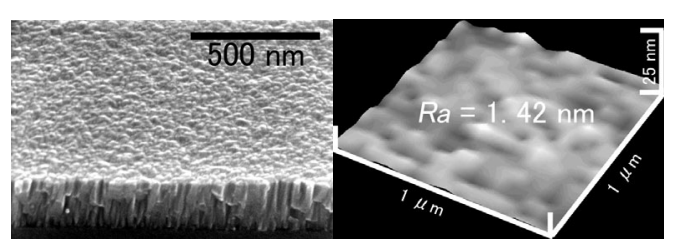

(a)

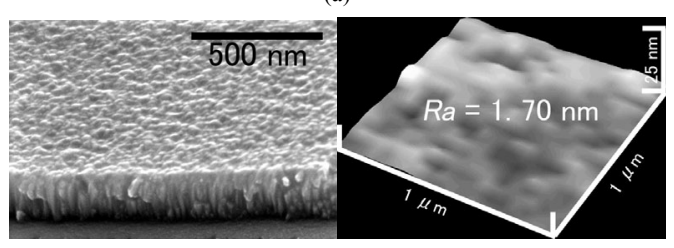

(b)

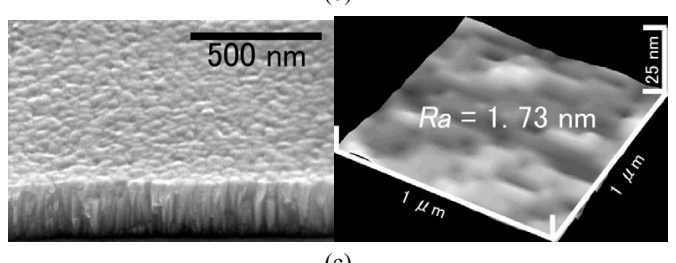

(c)

Fig. 6. FE-SEM and AFM images for the AZO films grown at different substrate temperature : (a) $200{ }^{\circ} \mathrm{C}$, (b) $100{ }^{\circ} \mathrm{C}$ and (c) $25{ }^{\circ} \mathrm{C}$

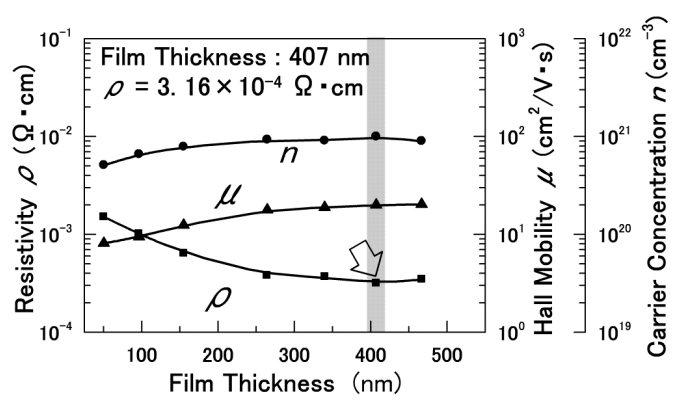

(a)

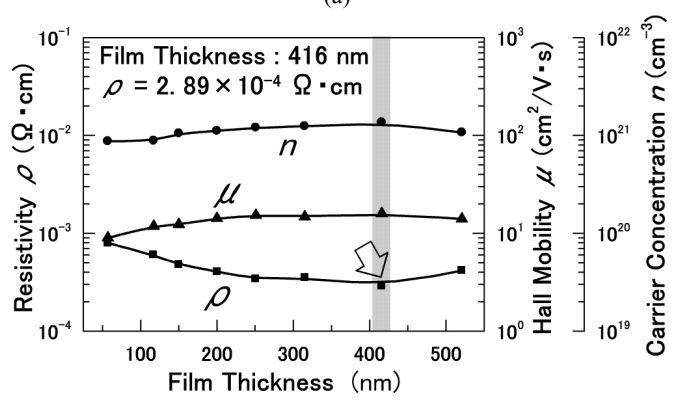

(b)

Fig. 7. Film thickness dependence of electrical properties for (a) AZO and (b) GZO films deposited using ArF excimer laser 


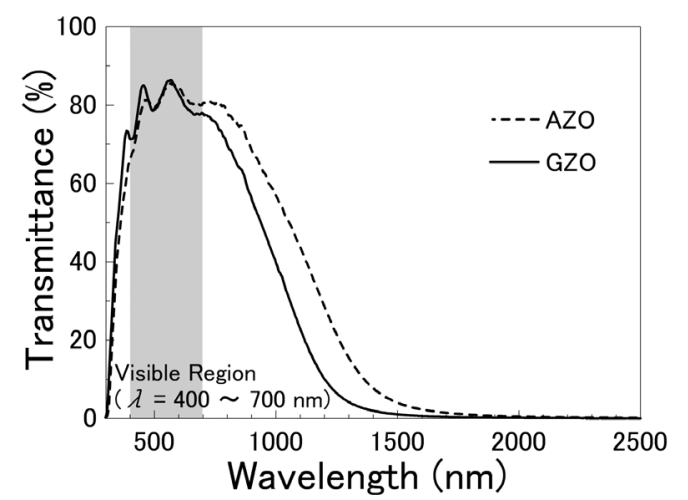

Fig. 8. Optical transmittance spectra for AZO and GZO films fabricated using ArF excimer laser

で低抵抗化を実現している(17) (21)が, 基板温度を室温として 成膜を行った場合でも膜中の酸素量を制御することでそれ らの透明導電膜の抵抗率に近い低抵抗な膜を得ることがで きることがわかった。

次に図 8 に最小抵抗率が得られた AZO および GZO 薄膜 を分光光度計にて透過率スペクトル測定した結果を示す。 この図より,いずれの膜も可視光領域 $(\lambda=400 \sim 700 \mathrm{~nm})$ における平均透過率は 80 \%以上を有し, 透明導電膜として 十分機能する值であった。また，これらのスペクトルの長 波長側は透過率の減少が確認できるが，これはプラズマ共 鳴現象による赤外域の反射による透過率の減少で, これら のことからもキャリア密度が大きな膜が得られていること がわかる。特に, GZO 透明導電膜のキャリア密度の值が AZO より大きいことからプラズマ共鳴現象による透過率の減少 が顕著に現れている。

次に図 9 に最小抵抗率が得られた AZO および GZO 薄膜 の XRD パターンの測定結果を示す。この図より, $\mathrm{ZnO}(0002)$ 面の回折ピークが確認できる。これは, $\mathrm{c}$ 軸配向すなわち基 板に対して垂直に結晶が成長していることを示唆してい る。両者を比較すると膜厚はほぼ同じであるが, $\mathrm{ZnO}(0002)$ 面の回折強度は僅かではあるが $\mathrm{GZO}$ 透明導電膜が大きな値 となった。また, $\mathrm{ZnO}(0002)$ 面の半值幅(FWHM)を求めたと ころ, $\mathrm{AZO}$ は $0.351^{\circ}, \mathrm{GZO}$ は $0.381^{\circ}$ となった。基板を 加熱して成膜を行った場合でも $0.3^{\circ}$ 程度 ${ }^{(26)}$ であることか ら, これらの值は室温成膜としては良好な值であった。

次にこれらの膜を FE-SEM および AFM にて膜表面・断面 を観察した結果を図 10 に示す。同図(a)および(b)を比較する と, 膜断面の柱状結晶が GZO でより明確に確認できる。ま た, 膜表面は GZO がより密に詰まった構造となっているこ

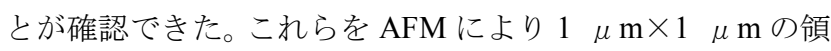
域にて表面平均粗さ $R a$ の值を求めたところ, AZO の場合 $R a=5.92 \mathrm{~nm}$ であったのに対し, GZO の場合 $R a=3.32 \mathrm{~nm}$ であった。次世代のフラットタイプディスプレイとして有 望視されている有機ELディスプレイに使用する場合, 膜の 平坦性が特に重要視されるため, GZO 透明導電膜が適して いることがこの結果よりわかった。

〈3.4〉 AZO 透明導電膜のプラズマプルームの場所依存

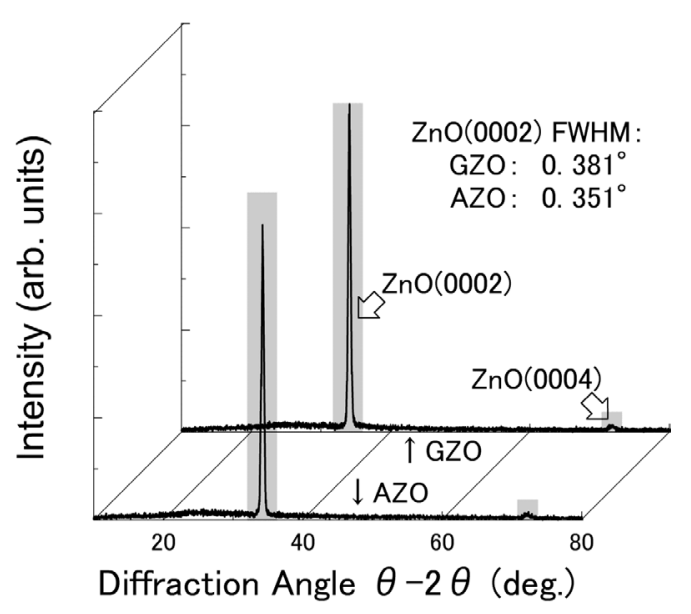

Fig. 9. XRD spectra for AZO and GZO films grown using ArF excimer laser

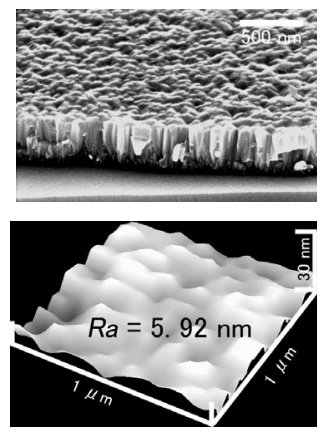

(a)
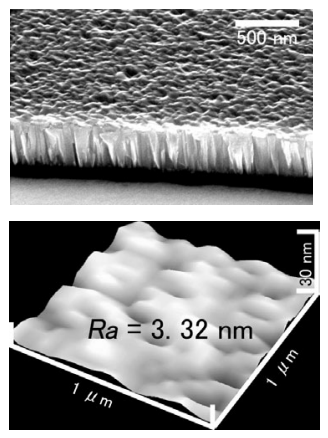

(b)
Fig. 10. FE-SEM and AFM images for (a) AZO and (b) GZO films prepared using ArF excimer laser

性次に, 成膜する際に発生するプラズマプルームの挙 動を調べるべく，低抵抗な膜が得られた $\operatorname{ArF}$ エキシマレー ザを用い透明導電膜の外周部分および膜中央部分の結晶構 造を FE-TEM により分析した結果を図 11 に示寸。同図(a) および(b)はいずれも膜の中央層部分であるが，この部分で は大きな結晶の乱れは確認できなかった。しかしながら同 図(c)および(d)の基板との界面部分では, 膜の外周部分すな わちプルームの外周部分では格子の乱れが確認できた。こ れは, プルームの中心付近でプラズマ密度が高く, 飛翔粒 子が活性化されていることにより基板に到達したときの再 結晶化が促進され, 格子の乱れが少なくなったものと考え られる。同様に図(e)および(f)の電子線回折パターンを見る と, 膜中央部分で明確な回折点が現れていることから, 結 晶性が良いことがわかった。

\section{4. まとめ}

$\mathrm{ArF}$ エキシマレーザおよび Nd:YAG レーザを用いた PLD 法で AZO および GZO 透明導電膜を作製し, 以下の結果を 得た。

（1） Nd:YAG レーザを用い，レーザ光源の波長を変化さ せて成膜することでアブレーション過程が異なり, 膜構造 


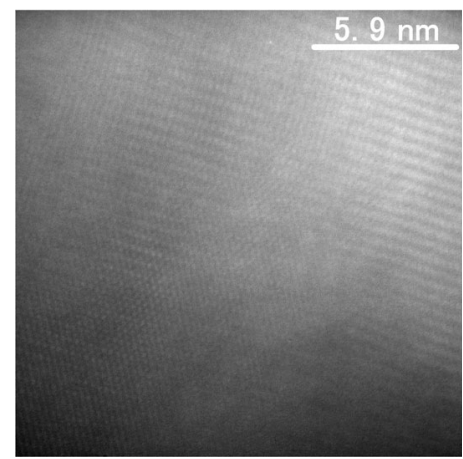

(a)

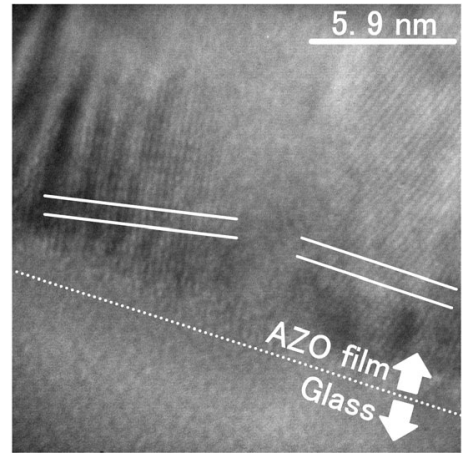

(c)

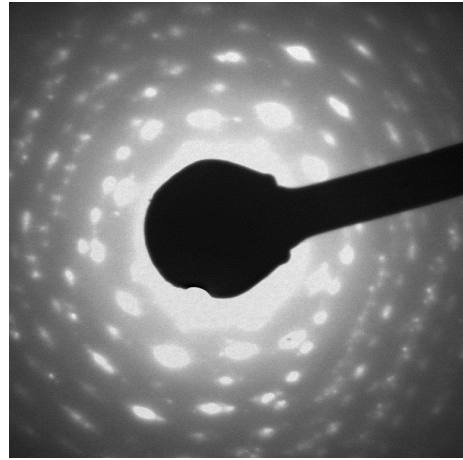

(e)

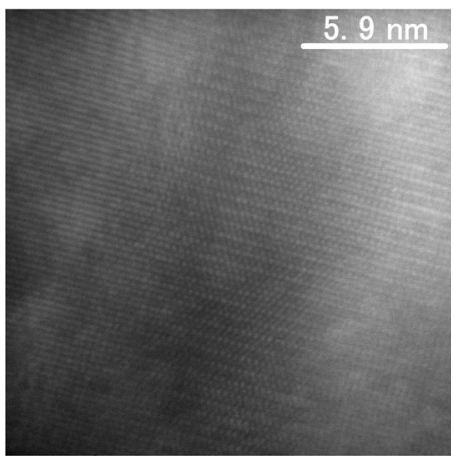

(b)

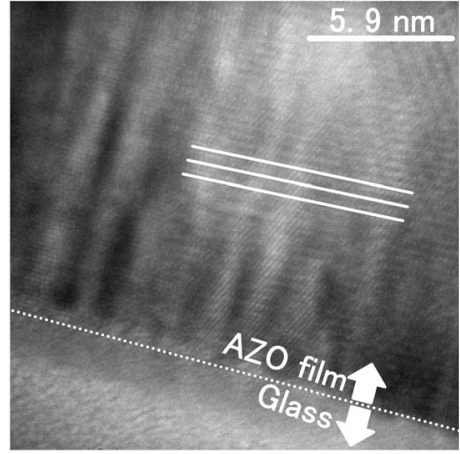

(d)
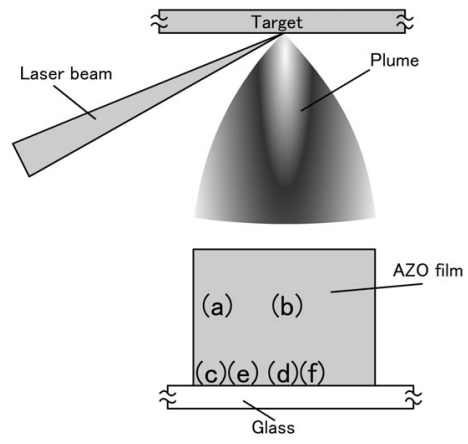

(g)

Fig. 11. High-resolution FE-TEM images of the AZO films fabricated with ArF excimer laser : (a)(b)crystal-lattice image in the center of the AZO films, (c)crystal-lattice image at the interface between the substrate and the AZO films, grown in the periphery of the plume, (d)crystal-lattice image at the interface between the substrate and the AZO films, grown in the center of the plume, (e)(f)electron diffraction pattern and (g) illustration of the position of (a) (f)

が大きく異なった $\mathrm{AZO}$ 透明導電膜となることがわかった。

(2) Nd:YAG レーザを用い, 基板温度を変化させて AZO 透明導電膜を作製することで基板温度を室温とした場合で も良好な電気的特性を有する透明導電膜が作製可能である ことがわかった。

(3) ArF エキシマレーザを用い， AZO および GZO 透明 導電膜を膜厚を変化させ基板温度室温として成膜すること で, AZO の場合, 膜厚が $407 \mathrm{~nm}$ の時, 最小抵抗率 $\rho=3.16$ $\times 10^{-4} \Omega \cdot \mathrm{cm}, \mathrm{GZO}$ の場合, 膜厚が $416 \mathrm{~nm}$ の時, 最小抵 抗率 $\rho=2.89 \times 10^{-4} \Omega \cdot \mathrm{cm}$ の基板温度を室温として成膜を 行った場合でも他の成膜方法に匹敵する低抵抗な值を得る ことができた。
（4） $\operatorname{ArF}$ エキシマレーザを用い，成膜する際に発生する プラズマプルームの挙動を調べた結果, プルームの中心付 近すなわちプラズマ密度が高い部分で成膜を行うことで, 基板と透明導電膜の界面部分で格子の乱れが極めて少ない 膜を作製可能であることがわかった。

(平成 18 年 2 月 28 日受付, 平成 18 年 6 月 14 日再受付)

\section{文献}

(1) A. Suzuki, T. Matsushita, T. Aoki, Y. Yoneyama, and M. Okuda : "Micro-Textured Milky ZnO:Ga Thin Films Fabricated by Pulsed Laser Deposition Using Second-Harmonic-Generation of Nd:YAG Laser", Jpn. J. Appl. Phys., Vol.38, No.1, L71 - L73 (1999-1) 
(2) A. Suzuki, T. Matsushita, T. Aoki, Y. Yoneyama, and M. Okuda : "Pulsed Laser Deposition of Transparent Conducting Indium Tin Oxide Films in Magnetic Field Perpendicular to plume”, Jpn. J. Appl. Phys., Vol.40, No.4, L401-L403 (2001-4)

( 3 ) H. Izumi, F. O. Adurodija, T. Kaneyoshi, T. Ishihara, H. Yoshioka, and M. Motoyama : "Electrical and structural properties of indium tin oxide films prepared by pulsed laser deposition", J. Appl. Phys., Vol.91, Issue 3. pp. $1213 \sim 1218(2002-3)$

(4) A. Suzuki, T. Matsushita, T. Aoki, A. Mori, and M. Okuda : "Highly conducting transparent indium tin oxide films prepared by pulsed laser deposition”, Thin Solid Films, Vol.411, Issue 1, pp.23-27 (2002-5)

(5) M. A. Morales-Paliza, R. F. Haglund, Jr., and L. C. Feldman : "Mechanisms of oxygen incorporation in indium-tin-oxide films deposited by laser ablation at room temperature", Appl. Phys. Lett., Vol.80, Issue 20. pp.3757-3759 (2002-5)

(6) E. M. Kaidashev, M. Lorenz, H. Von Wenckstern, A. Rahm, H. C. Semmelhack, K. H. Han, G. Benndorf, C. Bundesmann, H. Hochmuth, and M. Grundmann : "High electron mobility of epitaxial $\mathrm{ZnO}$ thin films on c-plane sapphire grown by multistep pulsed-laser deposition", Appl. Phys. Lett., Vol.82, Issue 22, p.3901 (2003-6)

( 7 ) M. Jayachandran, K. Sankaranarayanan, P. Misra, L. M. Kukreja, and C. Sanjeeviraja : "Epi-n-IZO thin films/ $\left\langle\begin{array}{llll}1 & 0 & 0\end{array}\right\rangle \mathrm{Si}, \mathrm{GaAs}$ and InP by L-MBE - - a novel feasibility study for SIS type solar cells", Solar Energy, Vol.77, Issue 2, p.193-201 (2004-8)

( 8 ) A. Tsukazaki, A. Ohtomo, T. Onuma, M. Ohtani, T. Makino, M. Sumiya K. Ohtani, S. F. Chichibu, S. Fuke, Y. Segawa, H. Ohno, H. Koinuma, and M. Kawasaki : "Repeated temperature modulation epitaxy for p-type doping and light emitting diode based on $\mathrm{ZnO}$ ", Nature Materials, Vol.4, No.1, pp.42-46 (2005-1)

(9) M. Lorenz, E. M. Kaidashev, A. Rahm, Th. Nobis, J. Lenzner, G. Wagner, D. Spemann, H. Hochmuth, and M. Grundmann : " $\mathrm{Mg}_{\mathrm{x}} \mathrm{Zn}_{1-\mathrm{x}} \mathrm{O}(0<=\mathrm{x}<0.2)$ nanowire arrays on sapphire grown by high-pressure pulsed-laser deposition", Appl. Phys. Lett., Vol.86, Issue 14 (2005-4)

(10) F. K. Shan, G. X. Liu, W. J. Lee, G. H. Lee, I. S. Kim, and B. C. Shin : "Aging effect and origin of deep-level emission in $\mathrm{ZnO}$ thin film deposited by pulsed laser deposition”, Appl. Phys. Lett., Vol.86, Issue 22 (2005-5)

(11) L. A. Bendersky, I. Takeuchi, K. S. Chang, W. Yang, S. Hullavarad, and R. D. Vispute : "Microstructural study of epitaxial $\mathrm{Zn}_{1-\mathrm{x}} \mathrm{Mg}_{\mathrm{x}} \mathrm{O}$ composition spreads", J. Appl. Phys., Vol.98, Issue 8 (2005-10)

(12) M. Rusop, K. Uma, T. Soga, and T. Jimbo : "Post-growth annealing of zinc oxide thin films pulsed laser deposited under enhanced oxygen pressure on quartz and silicon substrates", Mater. Sci. Eng. B, Vol.127, No.2-3, pp.150-153 (2006-2)

(13) Z. Songqing, Z. Yueliang, Z. Kun, L. Zhen, H. Peng, W. Shufang, X. Wenfeng, C. Zhenghao, L. Huibin, C. Bolin, and Y. Guozhen : "Violet luminescence emitted from Ag-nanocluster doped $\mathrm{ZnO}$ thin films grown on fused quartz substrates by pulsed laser deposition", Physica B, Vol.373, No.1, pp.154-156 (2006-3)

(14) T. Minami, H. Sato, K. Ohashi, T. Tomofuji, and S. Takata : "Conduction mechanism of highly conductive and transparent zinc oxide thin films prepared by magnetron sputtering", J. Crystal Growth, Vol.117, Issue 1-4, pp.370-374 (1992-2)

(15) H. Sato, T. Minami, S. Takata, T. Miyata, and M. Ishii : "Low temperature preparation of transparent conducting $\mathrm{ZnO}: \mathrm{Al}$ thin films by chemical beam deposition", Thin Solid Films Vol.236, Issue 1-2, pp.14-19 (1993-12)

(16) A. Suzuki, T. Matsushita, T. Fukuda, H Fujiwara, and M. Okuda : "Preparation of Transparent Conducting ZnO Thin Films Prepared by Laser Ablation Method Using Split Target", IEEEJ Trans. FM, Vol.117-A, No.4, pp.405-410 (1997-4) (in Japanese)

鈴木晶雄・松下辰彦・福田智也・藤原秀規・奥田昌宏 :「スプリット ターゲットを用いたレーザアブレーション法による $\mathrm{ZnO}$ 系透明導電 膜の作製」, 電学論 A, 117, 4, pp.405 410 (1997-4)

(17) M. Hiramatsu, K. Imaeda, N. Horio, and M. Nawata : "Transparent conducting $\mathrm{ZnO}$ thin films prepared by $\mathrm{XeCl}$ excimer laser ablation”, J. Vac. Sci. Technol. A, Vol.16, Issue 2, pp.669-673 (1998-3)

(18) Z. L. Pei, C. Sun, M. H. Tan, J. Q. Xiao, D. H. Guan, R. F. Huang, and L. S. Wen : "Optical and electrical properties of direct-current magnetron sputtered ZnO:Al films", J. Appl. Phys., Vol.90, Issue 7. pp.3432-3436 (2001-10)

(19) T. Minami, S. Ida, T. Miyata, and Y. Minamino : "Transparent conducting
$\mathrm{ZnO}$ thin films deposited by vacuum arc plasma evaporation", Thin Solid Films, Vol.445, Issue 2, pp.268-273 (2003-12)

(20) S. Shirakata, T. Sakemi, K. Awai, and T. Yamamoto : "Optical and electrical properties of $\mathrm{ZnO}$ films prepared by URT-IP method", Thin Solid Films, Vol.445, Issue 2, pp.278-283 (2003-12)

(21) H. Tanaka, K. Ihara, T. Miyata, H. Sato, and T. Minami : "Low resistivity polycrystalline $\mathrm{ZnO}: \mathrm{Al}$ thin films prepared by pulsed laser deposition”, J. Vac. Sci. Technol. A, Vol.22, Issue 4, pp.1757-1762 (2004-7)

(22) J. N. Zeng, J. K. Low, Z. M. Ren, T. Liew, and Y. F. Lu : "Effect of deposition conditions on optical and electrical properties of $\mathrm{ZnO}$ films prepared by pulsed laser deposition", Appl. Surf. Sci. Vol.197/198, pp.362-367 (2002-9)

(23) E. Holmelund, J. Schou, N. Larsen, and S. Tougaard : "Pure and Sn-doped ZnO films produced by pulsed laser deposition", Appl. Surf. Sci., Vol.197/198, pp.467-471 (2002-9)

(24) H. Agura, A. Suzuki, T. Aoki, T. Matsushita, H. Okinaka, S. Hoki, and M. Okuda : "Transparent Conducting Al-Zn-O Thin Films Prepared by Pulsed Laser Deposition in Magnetic Field Perpendicular to the Plume", J. Vac. Soc. Jpn., Vol.46, No.10, pp.752-755 (2003-10) (in Japanese) 安倉秀明・鈴木晶雄・青木孝憲 - 松下辰彦・沖中広和・甫木茂靖 $\cdot$ 奥田昌宏:「パルスレーザー堆積法でプルームに磁場を印加して作製 した Al-Zn-O 系透明導電膜」真空協会論誌「真空」, 46, 10, pp.752-755 (2003-10)

(25) H. Agura, H. Okinaka, S. Hoki, T. Aoki, A. Suzuki, T. Matsushita, and M. Okuda : "Low-Resistive and Transparent AZO Films Prepared by PLD in Magnetic Field”, IEEEJ Trans. EIS, Vol.123, No.11, pp.1916-1920 (2003-11) (in Japanese)

安倉秀明・沖中広和・甫木茂靖 - 青木孝憲 - 鈴木晶雄 ・松下辰彦 · 奥田昌宏 :「磁場を印加した PLD 法で作製した低抵抗 AZO 系透明導 電膜」, 電学論 C, 123, 11, pp.1916-1920 (2003-11)

(26) H. Agura, A. Suzuki, T. Matsushita, T. Aoki, and M. Okuda : "Low resistivity transparent conducting Al-doped $\mathrm{ZnO}$ films prepared by pulsed laser deposition", Thin Solid Films, Vol.445, Issue 2, pp.263-267 (2003-12)

(27) H. Agura, A. Suzuki, T. Aoki, T. Matsushita, and M. Okuda : "Doping Effect Dependence in Transparent Conducting ZnO Thin Films Prepared by Pulsed Laser Deposition in Magnetic Field Perpendicular to the Plume”, J. Vac. Soc. Jpn., Vol.47, No.3, pp.179-182 (2004-3) (in Japanese) 安倉秀明・鈴木晶雄・青木孝憲・松下辰彦・奥田昌宏 :「パルスレー ザー堆積法でプルームに磁場を印加して作製した酸化亜鉛系透明導 電膜のドーパント依存性」真空協会論誌「真空」, 47, 3, pp.179-182 (2004-3)

(28) Z. Jun, Z. Shengming, X. Changtai, H. Yin, X. Jun, G. Shulin, and Z. Rong: "Structural, optical and electrical properties of $\mathrm{ZnO}$ films grown on c-plane sapphire and (100)y-LiAlO 2 by pulse laser deposition", J. Cryst. Growth., Vol.280, No.1-2, pp.185-190 (2005-6)

(29) K. Manoj, M. R.m., A. Wakahara, M. Ishida, and A. Yoshida : "Pulsed laser deposition of epitaxial Al-doped $\mathrm{ZnO}$ film on sapphire with $\mathrm{GaN}$ buffer layer", Thin Solid Films, Vol.484, No.1-2, pp.174-183 (2005-7)

(30) L. Ming-Zheng, S. Chun-Tsung, Y. Hong-Chang, and C. Ming-Yau : "High-Quality ZnO Thin Films Grown by Fast Pulsed Laser Deposition without a Buffer Layer", Jpn. J. Appl. Phys., Part 2, Vol.44, No.28-32, pp.L995-L997 (2005-8)

(31) P. Sang-Moo, T. Ikegami, and K. Ebihara : "Investigation of Transparent Conductive Oxide Al-Doped $\mathrm{ZnO}$ Films Produced by Pulsed Laser Deposition", Jpn. J. Appl. Phys., Part 1, Vol.44, No.11, pp.8027-8031 (2005-11)

(32) H. Agura, T. Aoki, A. Suzuki, T. Matsushita, and M. Okuda : "Transparent Conducting ZnO Films Prepared by PLD in Electric Field”, IEEEJ Trans. EIS, Vol.125, No.11, pp.1641-1645 (2005-11) (in Japanese) 安倉秀明・青木孝憲・鈴木晶雄・松下辰彦・奥田昌宏 : 「電界を印加 した PLD 法で作製した酸化亜鉛系透明導電膜」, 電学論 C, 125, 11, pp.1641-1645 (2005-11)

(33) B. Ullrich and A. Erlacher : "Photosensitive hetero-pairing of $\mathrm{p}-\mathrm{GaAs} / \mathrm{n}-\mathrm{Si}$ by pulsed-laser deposition", J. Phys. D : Appl. Phys., Vol.38, pp.4048-4052 (2005-11)

(34) T. Maeda, H. Agura, T. Aoki, A. Suzuki, T. Matsushita, and M. Okuda : "Optimization of Transparent Conducting ZnO Films Deposited on PVC Substrate by PLD Method", IEEEJ Trans. EIS, Vol.126, No.1, pp.132-133 (2006-1) (in japanese) 
前田 剛・安倉秀明・青木孝憲・鈴木晶雄・松下辰彦・奥田昌宏 : 「PLD 法により PVC 基板上一作製した酸化亜鉛系透明導電膜の成膜条件 の最適化」, 電学論 C, 126, 1, pp.132-133 (2006-1)

(35) 電気学会 レーザアブレーションとその産業応用調査専門委員会 編 :「レーザアブレーションとその応用」，コロナ社 (1999-11)

安 倉 秀 明 （学生員） 1980 年 12 月 23 日生。 2004 年 3 月

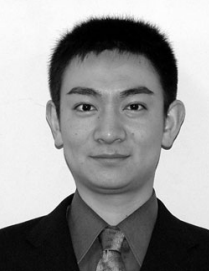
大阪産業大学大学院工学研究科電気電子工学 専攻博士前期課程修了。現在，同大学大学院工 学研究科生産システム工学専攻博士後期課程 在籍。現在に至る。修士 (工学)。応用物理学 会, 日本真空協会, レーザー学会, 日本表面科 学会会員。

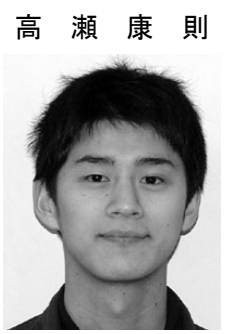

（学生員） 1983 年 3 月 11 日生。 2005 年 3 月大 阪産業大学工学部電気電子工学科卒業。現在, 同大学大学院工学研究科電気電子工学専攻博 士前期課程在籍。現在に至る。応用物理学会会 員。

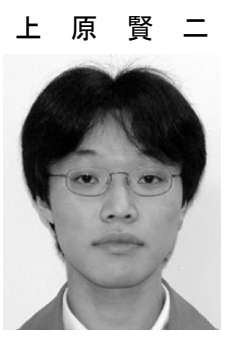

（学生員） 1983 年 5 月 11 日生。 2006 年 3 月大 阪産業大学工学部電気電子工学科卒業。現在, 同大学大学院工学研究科電子情報通信工学専 攻博士前期課程在籍。現在に至る。応用物理学 会会員。

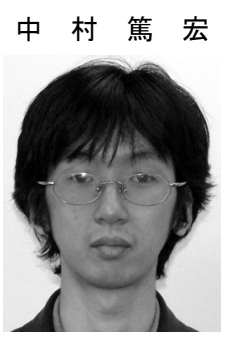

(学生員) 1983 年 9 月 25 日生。 2006 年 3 月大 阪産業大学工学部電気電子工学科卒業。現在, 同大学大学院工学研究科電子情報通信工学専 攻博士前期課程在籍。現在に至る。応用物理学 会会員。

東 村 佳 則

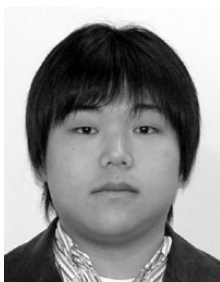

青 木 孝 憲

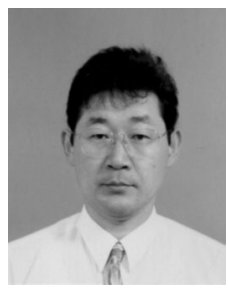

鈴 木 晶 雄

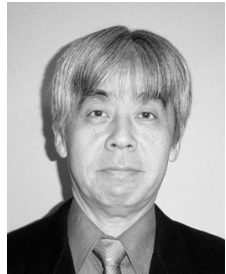

（正員） 1966 年 3 月 25 日生。 1988 年 3 月大阪 産業大学工学部電気電子工学科卒業。同年大阪 産業大学勤務。相変化, 酸化物光記録の研究に 従事。応用物理学会, 日本真空協会, 電子情報 通信学会、レーザー学会会員。 陽エネルギー学会, 日本表面科学会会員。応用物理学会プログラム 委員, 日本材料学会企画事業委員会委員, 半導体エレクトロニクス 部門委員会委員, 日本真空協会関西支部幹事。

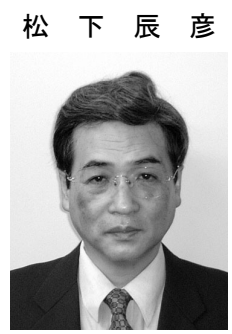

（正員） 1941 年 4 月 12 日生。1973 年 3 月大阪 府立大学大学院工学研究科博士課程修了。工学 博士。1983 年 4 月, 大阪産業大学工学部教授。 カルコゲナイド薄膜を用いたソーラーセルお よび光記録膜, $\mathrm{Bi}$ 系超伝導, $\mathrm{ZnO}$ 系透明導電膜, 環境半導体の研究に従事。電子情報通信学会, 応用物理学会, 日本物理学会, 米国光学会, 電 気化学協会, レーザー学会会員。

奥 田昌 宏

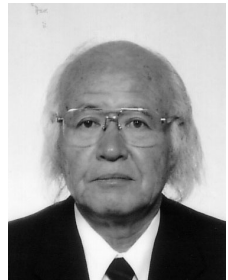

（正員） 1933 年 2 月 7 日生。 1957 年 3 月大阪 府立大学大学院工学研究科修士課程修了。工学 博士。同年 4 月，株式会社 島津製作所入社。 1982 年 12 月大阪府立大学工学部教授。1996 年 3 月大阪府立大学名誉教授。負性抵抗ダイオー ド，電子写真，カルコゲナイド薄膜を用いたソ ーラーセルおよび光記録膜, 光導波路, 分布帰 還型レーザー, 超伝導, $\mathrm{ZnO}$ 系透明導電膜の研 究に従事。電子情報通信学会, 応用物理学会, 日本物理学会, レー ザー学会会員。

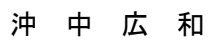

（非会員） 1980 年 9 月 4 日生。 2005 年 3 月大 阪産業大学大学院工学研究科電気電子工学専 攻博士前期課程修了。修士 (工学)。同年 4 月, 株式会社 日立ハイテクノロジーズ ナノテク ノロジー製品事業部 那珂アプリケーションセ ンタ 半導体計測グループ勤務。現在に至る。 